\title{
The Role of Morality in Economic Development
}

\author{
Emmanuel Ohifemen Elakhe \\ Dept. of Economics University of Port Harcourt, Nigeria. \\ emmanuelohi@ rocketmail.com +2348138199369+2348054861062
}

\section{Introduction}

Economic development has been sought by most developing and underdeveloped countries. Most of which have been preoccupied with several strategies and techniques which have not yielded the desired results. For Claude Ake (1996:96) he believes that for most developing countries particularly in Africa, is not so much that development project has failed, but that because of political conditions, it never really got started. An influential body of research in economic history, political economics and macroeconomics has shown that both economic and institutional backwardness are often a by-product of history. Appearing in countries or regions that were ruled centuries ago by despotic government or where powerful elites exploited uneducated peasants or slaves. Johnson and Robinson (2001) in Tebellini (2007).

Over the years economists had began to see economic development as a factor which transcends mere increases in gross domestic product and per capita income. Development is now view as a normative concept which cuts across all aspects of life including; social, political and economic. But not much emphasis has been paid to the social aspect. It is therefore not in doubt that the superstructure (social linings) influences the infrastructure (economy) of a country, thus development is not a one hundred meter race but a marathon. Seun88, Nigerian Muse (2012).

Our aim therefore is to identify the role of morality (which is a social aspect of development) in economic development. The paper is divided in to five sections. The first section looks at the origin of morality, the second considers the concept of economic development, the third assess the relationship between morality and economics, the fourth covers morality and economic development and the fifth concludes the paper.

\section{The Origin Of Morality}

Everybody wants to be treated in a nice and fair manner; nobody will like to be treated in a harsh cruel and unfriendly manner. This is at individual level, in the societal level some actions are weighed as generally acceptable while others are not, and what is considered acceptable or right in a particular society might be considered unacceptable or evil in another. The question now is what makes a particular behavior or action right and another behavior wrong? Are there generally accepted paradigms or rules in the universe that stipulates whether an action or behavior is right or wrong? Given that we live in a complex society with diverse beliefs, ideologies, culture, norms, values and religion.

Morality has been defined as issues that have to do with right and wrong, good and evil, acceptable and unacceptable etc. It is the mental disposition of characteristic of behaving in a manner intended to produce morally good results. The above question leads us to what the origin of moral values are in any given society or nation. According to Phil B. morality is rooted to nature and not just mankind. To buttress this fact we discover that some animals with lower intelligence than man have some sense of morality. For instance some dogs appear to know when they are doing or did something wrong. Some times dogs would simply look around to see if they were caught stealing food or if they got away with it. On the other hand, as mankind developed higher intelligence or nurture (this intelligence could be from religion, education, culture, environment etc.) the concept of morality and ethics became better developed in human psyche too.

According to Benjamin Friedman morality is gauged by such elements as openness of opportunity, tolerance, economic and social mobility fairness and democracy. He further stressed that morality is incomeelastic and has nothing to do with the image of God in all of us or with personal salvation. People will act nice when they can afford to. Claude Ake (1981) also stressed that those from the economically privileged groups tend to be better educated, 'more cultured', to have higher social status, to be more 'successful' professionally and politically and tend to be interested in preserving the existing social order.

Putting this three roots together i.e. nature, development of intelligence or nurture and income. We can therefore deduce that a given moral behavior is a product of the combination of nature, intelligence developed over time and personal income.

Symbolically we can represent it as follows:

Let; $\quad$ Morality represented as $\mathrm{M}$ 
Nature - $\mathrm{N}_{\mathrm{o}}$

Intelligence developed - ID

Personal income - Y

We assume that nature $\mathrm{N}_{\mathrm{o}}$ is a fixed component since it is not determined by man's choice or his environment. Also let intelligence developed (ID) and personal income (Y) be the variable component since they can be influenced by man's choice and environment.

We will also identify another component called the stochastic component or error term represented as U. this component takes care of all other factors that are likely to affect man's morality other than the three components identified above.

Specification

We therefore specify our model as follows

$$
\mathbf{M}=\mathbf{N}_{\mathbf{o}}+\mathbf{I D}+\mathbf{Y}+\mathbf{U}
$$

Let's assume that nature $\left(\mathrm{N}_{\mathrm{o}}\right)$ determines $20 \%$ of a person's moral values and $75 \%$ is determined by intelligence developed (nurture) and personal income, and then 5\% represents random element or variable. We can therefore infer that the more intelligence a person acquires, the greater the influence it will have on his moral behavior, also the higher his income, the greater the influence it will have on his moral behavior.

\section{Economic Development}

The concept of economic development had evolved over time. 'The problem of development came to the fore at the end of the second world war in 1945. Initially the problem was seen as an economic one to be tackled largely by economists. Arising from the massive poverty that afflicted the vast majority of the people of the world. Economists initially interpreted economic development mainly in terms of economic growth'. Okowa (1996:11). Some definitions have been identified below;

Michael Todaro described development as "A perceived multidimensional process involving the reorganization and re-orientation of entire economic and social systems. In addition to improvements in income and outputs, it typically involves radical changes in institutional, social and administrative structures as well as popular attitudes and in many cases even customs and beliefs (Todaro, 1982:56)

Goulet (1992) summarizes 'development under six of components

i) An economic component dealing with the creation of wealth and improved conditions of material life, equitably distributed.

ii) A social ingredient measured as well being in health, education, housing and employment.

iii) A political dimension including such values as human rights, political freedom, enfranchisement, and some form of democracy.

iv) A cultural dimension in recognition of the fact that cultures confer identity as a self worth to people.

v) A full-life paradigm, which refers to meaning systems, symbols and beliefs concerning the ultimate meaning of life and history. and

vi) A commitment to ecologically sound and sustainable development so that the present generation does not undermine the position of future generations.

\section{Morality And Economics}

If morality has something to do with economic development then it must also be connected to economics as a field of study. As a matter of fact it is an aspect of economics called 'moral economics'. The purpose of this section is to identify the relationship between morality and economics. In order to accomplish this let us consider the following approach by the Mackeever Institute of Economic policy (MIEPA).

\section{Government Establish And Modify Economic Policy}

To begin with we will agree that governments are responsible for creating laws, public order, rules of exchange, money supply, public goods, public policies etc. while many other aspects of life are created personally, within a family or clan, community or neighborhood unit or collectively in civil non-governmental organizations. This is the basis to which economic principles are formed. The principles describe how goods are created, acquired and distributed. So it is possible for the government and civil society to create or change those rules to accommodate a wide variety of cultural and social values. It is also possible for government to include a moral component to the economic rules of the society. For instance an economic principle with no moral component established by governmental authorities may interfere with family cohesion.

\section{Free Market Moral Policy}

Economic theory and policy can help provide virtue in the market by ensuring that markets are competitive and that producers of products which have the potential to harm people are closely regulated. Thus pro-competition and anti-monopoly rules and regulations become supportive of virtue and thus moral. 


\section{Virtues Of Socialist Economics}

Socialist economics provide for all citizens many of the benefits of civilization, health, education, freedom from hunger etc. these appeal to basic human desire to see all people treated fairly.

\section{Morality And Economic Development}

Development defined in terms of morality has been described as a normative concept which applies to the context of people's sense of morality (right or wrong, good or bad etc.), Shilparamidi (2013). You will therefore agree with the fact that whatever is not generally acceptable as right or good in a particular society or nation cannot contribute to the development of that nation. If morality has to do with issues of right and wrong, good and evil, acceptable and unacceptable etc. it therefore implies that individual values and convictions are involved. These values and convictions plays a critical role in determining human behavior and thus economic performance.

A wide range of economic lapses have been associated with failure in the government and other social institutions. No wonder Jeremey Bentham, a proponent of utilitarianism stated that 'utilitarianism is more specifically applied to the proposition that the supreme objective of moral actions is the achievement of the greatest number (this objective is also considered the aim of all legislations and the ultimate criterion of all social institutions). In most of the underdeveloped and developing countries these objectives are not achieved due to lack of good governance, corruption among the leaders, wide spread of moral hazard in public and private institutions, institutional failure, inadequate law enforcement agency etc.

Most theories and recommendations for development have focused on the economic institutional framework ignoring the socio-economic framework, which determines in the short run the pace of development of any given society. Seun88, Nigerian Muse (2012). These non-economic aspects in totality constitute the superstructure while the economic system constitutes the infrastructure, Okowa (1996). The non-economic aspects in many ways determines the economic aspects. Thus if we neglect the superstructure the infrastructure will be ineffective and deficient.

\section{Empirical Evidence - The Case Of Public And Private Enterprise In Nigeria}

If we take the case of public and private enterprise or in the Nigeria context. In Nigeria and in most part of the world no business owner, entrepreneur or capitalist will handle his business or enterprise with levity. Most private enterprises in Nigeria perform more efficiently than public enterprises. For instance most of our private universities which started operation long after the public universities where established are already taking the lead in the rank of universities in Nigeria. On the contrary our public institutions such as the federal universities have been encumbered by dilapidated structures, disarticulated academic calendar, strikes, substandard lecturers, poor academic performance etc. This has led to the flow of monetary income in the form of school fees that would have been invested in the educational sector to other foreign universities.

These discrepancies are due to differences in adherence to moral values while most private employees are propelled to adhere to the moral values of the organization, most public or government workers neglect these values and assume an 'I don't care attitude'.

\section{Conclusion}

Since every nation, state, community, organization or individual is guided by one moral standard or the other which have evolved over time to achieve a particular goal of growth and development. It is therefore imperative to state here that adherence to moral values is a key indicator to achieving economic development in a nation. Individual values and behaviors have been proven to be key factor that promotes economic performance. Therefore if moral values are promoted, the economy will also perform well since the economy cannot be separated from the people.

A famous Italian politician once said 'We have built Italy we must now seek to create an Italian". Economic development in a nation might just be a mere illusion if we attempt to achieve it independent of the people. It is therefore my view that the foundation of economic development in any nation begins from effective and efficient moral and value system.

\section{References}

[1]. Ake Claude (1981), A Political Economy of Africa. Longman Nigeria Plc.

[2]. Ake Claude (1996), Democracy and Development in Africa. Spectrum Books Limited, Ibadan Nigeria.

[3]. Aiyede Remi, The State, Values and Development; Towards Re-orienting the Nigerian Youth for Positive Leadership. University of Ibadan, Nigeria.

[4]. B. Phil, The Origin of Morality and Ethics.

[5]. Friedman Benjamin (2005), The Moral Consequences of Economic Growth. New York: knopf. ISBN: 0-6799-44891

[6]. Joeblackarf (2013), What is the Development.

[7]. Nsama69 (2012), Measures of Development. 
[8]. Okowa Willie (1996), How The Tropics Underdeveloped the Negro; A Questioning Theory of Development. University of Port Harcourt, Nigeria.

[9]. Seun88 (2012), Morality and Development; The Path to Advancement. General Articles Nigerian Muse.

[10]. Tabellini Guido (2012), Morality Matters for Economic Performance, Bocconi University and CEPR Research Fellow.

[11]. Todaro P. Michael, Stephen C. Smith, Economic Development. $11^{\text {th }}$ Edition.

[12]. http//www.studymode.com/essays

[13]. http//www.mkeever.com

[14]. http//www.wikipedia.org 